\title{
Evaluation of analgesic, anti-inflammatory and CNS activities of the methanolic extract of Syzygium Samarangense bark.
}

\author{
Shabnam Mollika ${ }^{1},{ }^{*}$ Mst. Luthfun Nesa ${ }^{1}$, Mst. Shirajum Munira ${ }^{1}$, Dr. Monirul \\ Islam $^{1}$, Md.Wahed Sayem ${ }^{2}$, Nasima Parvin ${ }^{1}$, Md.Nasim ${ }^{1}$ \\ ${ }^{I}$ Department of Pharmacy, Atish Dipankar University of Science and Technology, Dhaka, Bangladesh \\ ${ }^{2}$ Jahangir nagar University.
}

\begin{abstract}
Syzygium Samarangense (red jamrul in Bangladesh) is a potential medicinal drug. We aimed to evaluate the analgesic, anti-inflammatory and CNS activities of the methanolic extract of Syzygium Samarangense bark in mice. The analgesic activity was examined by acetic acid induced writhing and formalin tests. The anti-inflammatory activity was studied using carrageenan induced hind paw edema model. The analgesic activity of the methanolic extract of Syzygium Samarangense bark was evaluated by acetic acid induced writhing and formalin tests at the dose of $100 \mathrm{mg} / \mathrm{kg}$ and $200 \mathrm{mg} / \mathrm{kg}$, significantly $(\mathrm{p}<0.05)$ reduced the writhing caused by acetic acid and the number of licks induced by formalin in a dose dependent manner.The extract of Syzygium Samarangense bark caused significant $(\mathrm{p}<0.05)$ inhibition of carrageenan induced paw edema after $4 \mathrm{~h}$ in a dose dependent manner. The CNS depressant activity was evaluated by observing the reduction of locomotor and exploratory activities in the open field and hole cross tests at a dose of $100 \mathrm{mg} / \mathrm{kg}$ and $200 \mathrm{mg} / \mathrm{kg}$ body weight. The findings of the study suggested that the methanolic extract of Syzygium Samarangense bark has strong analgesic, moderate effect against inflammation and significant CNS effects, conforming the traditional use of this plant for inflammatory pain alleviation.
\end{abstract}

KEYWORDS:, Analgesic, Anti-inflammatory, Bark, CNS activities ,Methanolic extract of Syzygium Samarangense, Pain

\section{INTRODUCTION}

The use of the medicinal plants is increasing in many countries where $35 \%$ of drugs contain natural products. At present, thousands of plant metabolites are being successfully used for the treatment of variety of diseases. The investigation of the efficacy of plant-based drugs used in the traditional medicine have been paid great attention because they are cheap, have little side effects and according to WHO still about $80 \%$ of the world population rely mainly on plant based drugs. In Bangladesh thousands of species are known to have medicinal value and the use of different parts of several medicinal plants to cure specific ailments has been in vogue since ancient times. The beneficial medicinal effects of plant materials typically results from combinations of secondary product present in plant such as alkaloids, steroids, tannins, phenol compounds, resins, gums, flavonoids and fatty acids which are capable of producing definite physiological action on body.

Syzygium samarangense belongs to the Myrtaceae family and is among the fruits of economic importance in Asia and Taiwan. Common names of Syzygium samarangense are wax apple, love apple, java apple, chomphu (in Thai), Man (in Vietnam), bellfruit (In Taiwan), Jamaican Apple, Otaheti Apple (in Jamaica), jambu air (in Indonesian), water apple, mountain apple, cloud apple, jambu air ("water guava" in Malay), wax jambu, rose apple, bell offruit, makopa, tambis (Philippines), and chambekka in Malayalam, jamrul (in Bengali), and jumbu (Sri Lanka). Syzygium samarangense is a tropical tree growing to $12 \mathrm{~m}$ tall, with evergreen leaves $10-25 \mathrm{~cm}$ long and $5-10 \mathrm{~cm}$ broad. The flowers are white, $2.5 \mathrm{~cm}$ diameter, with four petals and numerous stamens. The fruit is a bell-shaped, edible berry, with colors ranging from white,to red or green to red, purple, or crimson, to deep purple 4-6 cm long in wild plants. The flowers and resulting fruit are not limited to the axils of the leaves, and can appear on nearly any point on the surface of the trunk and branches. When mature, the tree is considered a heavy bearer, yielding a crop of up to 700 fruits.

Its leaves, roots, bark, and fruit all have potential medical applications. Some Myrtaceae plants have reportedly been used as medicinal herbs for the treatment of bronchitis, asthma, diabetic mellitus, and inflammation syndromes. They exert potent free radical scavenging, antioxidation, antimutation, and anticancer activities.Previous study identified that extracts from guava (Psidium guajava L.) leaves displayed antihyperglycemic ability in Type 2 diabetic mice and recognized quercetin as the major active component in the extracts. The leaves of wax apple also contain abundant phytochemicals, including ellagitannins, flavanones, 
flavonol glycosides, proanthocyanidins, anthocyanidins, triterpenoids, chalcones, and volatile terpenoids. Wax apple fruit has reportedly demonstrated antihyperglycemic activity in alloxan-induced (Type 1 DM) diabetic mice. Syzygium samarangense invites great attention for researchers worldwide due to its various pharmacological activities such as anti-diabetic, antimicrobial activity, antiviral activity, spasmolytic activity, protease inhibitory/intiamnesiac activity, immunomodulatory activity, antihyperglycaemic activity, analgesic and antiinflammatory activities [Edible Medicinal And Non-Medicinal Plants: Volume 3, Fruits] and woundhealing. The red fruits are juicier and more flavorful and suitable for eating out-of-hand. In Malaya, the greenish fruits are eaten raw with salt or may be cooked as a sauce. They are also stewed with true apples. The flowers are astringent and used in Taiwan to treat fever and halt diarrhea. The phytochemicals in the Java apple tree show some antibiotic action against staphylococcus aureus, candida albicans and mycrobacter smegmatis. Investigators have found the flowers principal constituent to be tannin. The red, hard wood is used for constructing huts in the Andaman and Nicobar Islands.

The fruits are used in traditional medicine to cure diabetes.Several syzygium species are reported to possess antibacterial, antifungal and anti- inflammatoryactivities The flavonoids isolated from S. samarangense were reported to possess antihyperglycemic activity, spasmolytic activity and immunomodularity activity fractionation of the methanolic extracts of the pulpand seeds of the fruits of Syzygium samarangense led to the identification of four cytotoxic chalcones and eight antioxidants. Prolyl endopeptidase inhibitors were isolated from the hexane extract of the leaves of S. samarangense. A new triterpene methyl-3-epi-betulinate in its native form and 4', 6'-dihydroxy-2'-methoxy-3', 5'-dimethyl chalcone along with ursolic acid, jacoumaric acid and arjunolic acid have been isolated from the aerial parts of Syzygium samarangense.

\subsection{Animal selection:}

\section{MATERIALS AND METHOD}

Swiss albino mice (25-30g) were used for assessing biological activity. The animals were maintained under standard laboratory conditions and had free access to food and water ad libitum. The animals were allowed to acclimatize to the environment for 7 days prior to experimental session. The animals were divided into different groups, each consisting of five animals which were fasted overnight prior to the experiments. Experiments on animals were performed in accordance with guidelines of the Institutional Animal Ethics Committee, Atish Dipankar University of Science \& Technology, Dhaka, Bangladesh. Animal treatment and maintenance for acute toxicity and analgesic effects were conducted in accordance with the Principle of Laboratory Animal Care (NIH publication No. 85-23, revised 1985) and the Animal Care and Use Guidelines of Atish Dipankar University of Science \& Technology, Dhaka, Bangladesh.

\subsection{Collection of Plant materials}

The bark of the Syzygium Samarangense (red jamrul) were collected from the adjoining area of Jahangirnagar University Campus, Bangladesh during Aril 2013. The plant material was taxonomically identified by the National Herbarium of Bangladesh-Dhaka.

\subsection{Chemicals}

Diclofenac Na, Ibuprofen and Diazepam were obtained from Square Pharmaceuticals Ltd., Bangladesh, Acetic acid was collected from Merck, Germany. Normal saline water (0.9\%) $\mathrm{NaCl}$ was brought from Beximco Infusion Ltd. Bangladesh.Formalin, carageenan and all other chemicals were of analytical grade.

\subsection{Preparation of plant extract}

The plant material was shade-dried with occasional shifting and then powdered with a mechanical grinder, passing through sieve \#40, and stored in a tight container. The dried powder material $(1.2 \mathrm{~kg}) \mathrm{was}$ refluxed with methanol for three hours. The total filtrate was concentrated to dryness, in vacuo at $40^{\circ} \mathrm{C}$ to render the methanol extract $(310 \mathrm{~g})$. The obtained methanolic extract was concentrated reddish black colored.The extract was preserved in a air-tight container as a crude extract sample.

\subsection{Acute toxicity study}

Acute oral toxicity assay was performed in healthy nulliparous and non pregnant adult female albino Swiss mice $(25-30 \mathrm{~g})$ divided into different groups. The test was performed using increasing oral dose of the methanolic extract of Syzygium Samarangense bark in water (50,100, 200, 500, $1000 \mathrm{mg} / \mathrm{kg}$ body weight), in $20 \mathrm{ml} / \mathrm{kg}$ volume to different test groups. Normal group received water. The mice were allowed to feed $\mathrm{ad}$ libitum, kept under regular observation for $48 \mathrm{~h}$, for any mortality or behavioral changes (Sanmugapriya and Venkataraman, 2006). 


\subsection{Analgesic activity:}

\subsubsection{Acetic acid-induced writhing test:}

The analgesic activity of the samples was also studied using acetic acid-induced writhing model in mice. The animals were divided into six groups with five mice in each group. Group I animals received vehicle (water), Group II received Diclofenac $\mathrm{Na}$ at $10 \mathrm{mg} / \mathrm{kg}$ body weight while animals of Group III and IV were treated with $100 \mathrm{mg} / \mathrm{kg}$ and $200 \mathrm{mg} / \mathrm{kg}$ body weight (p.o./per oral) of the methanolic extract of Syzygium Samarangense bark.. Test samples and vehicle were administered orally $30 \mathrm{~min}$ before intraperitoneal administration of $1.0 \% \mathrm{v} / \mathrm{v}$ acetic acid but Diclofenac-Na was administered intraperitonially $15 \mathrm{~min}$ before injection of acetic acid. After an interval of 5 min, the mice were observed for specific contraction of body referred to as 'writhing' for the next 10 min (Ahmed et al., 2004).

\subsubsection{Formalin test}

The antinociceptive activity of the drugs was determined using the formalin test described by Dubuission and Dennis (1977). Control group received 5\% formalin. $20 \mu 1$ of 5\% formalin was injected into the dorsal surface of the right hind paw 60 min after administration of the extract of Syzygium Samarangense bark $(100 \mathrm{mg} / \mathrm{kg}$ and $200 \mathrm{mg} / \mathrm{kg}$, per oral) and $30 \mathrm{~min}$ after administration of Diclofenac $\mathrm{Na}(10 \mathrm{mg} / \mathrm{kg}$, i.p./intraperitoneal). The mice were observed for $30 \mathrm{~min}$ after the injection of formalin, and the amount of time spent licking the injected hind paw was recorded. The first $5 \mathrm{~min}$ post formalin injection is referred to as the early phase and the period between 15 and $30 \mathrm{~min}$ as the late phase. The total time spent licking or biting the injured paw (pain behavior) was measured with a stop watch.

\subsection{Anti-inflammatory activity}

\section{Carrageenan induced paw edema test in mice}

Swiss albino mice $(25-30 \mathrm{~g})$ were divided into six groups of five animals each. The test groups received $100 \mathrm{mg} / \mathrm{kg}$ and $200 \mathrm{mg} / \mathrm{kg}$ body weight, ( p.o./per oral) of the methanolic extract of Syzygium Samarangens bark. The reference group received Ibuprofen $(10 \mathrm{mg} / \mathrm{kg}$ body weight, per oral) while the control group received 1 $\mathrm{ml} / \mathrm{kg}$ body weight normal saline. After $1 \mathrm{~h}, 0.1 \mathrm{ml}, 1 \%$ carrageenan suspension in normal saline was injected into the subplanatar tissue of the right hind paw. The paw volume was measured at $1,2,3$ and $4 \mathrm{~h}$ after carrageenan injection using a micrometer screw gauge. The percentage inhibition of the inflammation was calculated from the formula:

$$
\% \text { inhibition }=\left(1-D_{t} / D_{0}\right) \times 100
$$

Where, $D_{o}$ was the average inflammation (hind paw edema) of the control group of mice at a given time, $D_{t}$ was the average inflammation of the drug treated mice at the same time (Winter et al., 1962).

\subsection{Statistical analysis}

All values were expressed as the mean \pm SEM of three replicate experiments. The analysis was performed by using SPSS statistical package for WINDOWS (version 16.0; SPSS Inc, Chicago). Results related to the reducing power activities were statistically analyzed by applying the Student $t$-test and $p<0.001$ were considered to be statistically significant. All data are subjected to ANOVA followed by Dunnett's test and $p<0.05$ were considered to be statistically significant.

\section{Acute Toxicity Studies}

\section{III . RESULTS}

The acute toxicity studies mainly aim at establishing the therapeutic index, i.e., the ratio between the pharmacologically effective dose and the lethal dose on the same strain and species. The methanolic extract of Syzygium Samarangense bark was safe up to a dose of $1000 \mathrm{mg} / \mathrm{kg}$ (p.o.) body weight. Behavior of the animals was closely observed for the first $3 \mathrm{~h}$ then at an interval of every $4 \mathrm{~h}$ during the next $48 \mathrm{~h}$. The methanolic extract did not cause mortality in mice during $48 \mathrm{~h}$ observation but little behavioral changes, locomotor ataxia, diarrhea and weight loss were observed. Food and water intake had no significant difference among the group studied.

\section{In vivo analgesic activity}

\section{Acetic acid-induced writhing test}

Table 1. shows the effects of both extract of on acetic acid-induced writhing in mice. The oral administration of the methanolic extract of Syzygium Samarangense bark significantly $(p<0.05)$ inhibited writhing response induced by acetic acid in a dose dependent manner. 


\section{Formalin test}

The methanolic extract of Syzygium Samarangense bark (100 mg/kg and $200 \mathrm{mg} / \mathrm{kg}$, p.o.) significantly $(\mathrm{P}<0.05)$ suppressed the licking activity in either phase of the formalin-induced pain in mice in a dose dependent manner (Table 2). The methanolic extract of Syzygium Samarangense bark at the dose of $200 \mathrm{mg} / \mathrm{kg}$ body weight, showed the almost similar licking activity against both phases of formalin-induced pain than that of the standard drug diclofenac Na.

\section{Anti-inflammatory activity \\ Carrageenan induced paw edema test}

Table 3 showed that the anti-edematous effects of orally administered methanolic extract of Syzygium Samarangense bark on carrageenan induced paw edema in mice- a dose dependent moderate type of antiinflammatory activity but statistically significant $(\mathrm{P}<0.05)$. Methanolic extract of Syzygium samarangens bark showed anti-inflammatory effects at $200 \mathrm{mg} / \mathrm{kg}$ dose $(59.82 \%$ of inhibition), whereas standard diclofenac showed (84.18\% of inhibition) of paw edema.

\section{DISCUSSION}

Acetic acid induced writhing response is a sensitive procedure to evaluate peripherally acting analgesics and represents pain sensation by triggering localized inflammatory response. Such pain stimulus leads to the release of free arachidonic acid from the tissue phospholipid (Ribeiro et al., 2000). The response is thought to be mediated by peritoneal mast cells (Voilley, 2004), acid sensing ion channels (Hossain et al., 2006) and the prostaglandin pathways (Adzu et al., 2003). The organic acid has also been postulated to act indirectly by inducing the release of endogenous mediators, which stimulates the nociceptive neurons that are sensitive to NSAIDs and narcotics (Alam et al., 2012). It is well known that non-steroidal anti-inflammatory and analgesic drugs mitigate the inflammatory pain by inhibiting the formation of pain mediators at the peripheral target sites where prostaglandins and bradykinin are proposed to play a significant role in the pain process (Kim et al., 2004). Therefore, it is likely that the methanolic extract of Syzygium samarangens bark might have exerted its peripheral antinociceptive action by interfering with the local reaction caused by the irritant or by inhibiting the synthesis, release and/or antagonizing the action of pain mediators at the target sites. The above findings clearly demonstrated that both central and peripheral mechanisms are involved in the antinociceptive action of the methanolic extract of Syzygium samarangens bark. Interestingly, compounds like flavonoids and steroids, triterpenes in part, have been shown to possess anti-inflammatory, analgesic activity and the claim made by Pritam et al. (2011).

The formalin model normally postulates the site and the mechanism of action of the analgesic. This biphasic model is represented by neurogenic (0-5 min) and inflammatory pain (15-30 min), respectively (Hunskaar and Hole, 1987). Drugs that act primarily on the central nervous system such as narcotics inhibit both as steroids and NSAIDs suppress mainly the late phase (Alam et al., 2012). The suppression of neurogenic and inflammatory pains by the extract might imply that it contains active analgesic principle that may be acting both centrally and peripherally. This is an indication that the extract can be used to manage acute as well as chronic pain. The mechanism by which formalin triggers C-fibers activation remained unknown for a relatively long time. Recently, however, McNamara et al., (2007) demonstrated that formalin activates primary afferent neurons through a specific and direct on TRPA1, a member of the transient receptor potential family of cation channels, expressed by a subset of C-fiber nociceptors, and this effect is accompanied by increased influx of $\mathrm{Ca}^{2+}$ ions. TRPA1 cation channels at primary sensory terminals were also reported to mediate noxious mechanical stimuli (Kerstein et al., 2009). These experiments suggest that $\mathrm{Ca}^{2+}$ mobilization through TRPA1cation channels is concomitant with noxious chemicals and mechanical stimuli as they produce their analgesic action. It is likely that the inhibitory effect methanolic extract of Syzygium samarangens bark to pain response is due to inhibit the increase of the intracellular $\mathrm{Ca}^{2+}$ through TRPA1, presumably evoked by formalin. So, the extract of Syzygium Samarangense bark may contain substances that affect the metabolism of $\mathrm{Ca}^{2+}$.

Carrageenan induced edema has been commonly used as an experimental animal model for acute inflammation and is believed to be biphasic. The early phase (1-2h) of the carrageenan model is mainly mediated by histamine, serotonin and increased synthesis of prostaglandins in the damaged tissue surroundings. The late phase is sustained by prostaglandin release and mediated by bradykinin, leukotrienes, polymorphonuclear cells and prostaglandins produced by tissue macrophages (Antonio and Brito, 1998; Gupta et al., 2006; Sawadogo et al., 2006). Since the extract significantly inhibited paw edema induced by carrageenan in the second phase and this finding suggests a possible inhibition of cyclooxygenase synthesis by the extract and this effect is similar to that produced by non-steroidal anti-inflammatory drugs such as ibuprofen, whose mechanism of action is inhibition of the cyclooxygenase enzyme. Flavonoids and saponins are well known for 
their ability to inhibit pain perception as well as anti-inflammatory properties due to their inhibitory effects on enzymes involved in the production of the chemical mediator of inflammation (Pin et al., 2010). This hypothesis is strongly supported by the previous study, which has shown that methanolic extract of Syzygium samarangens bark possess anti-inflammatory activity due to the presence of flavonoid content (Koblyakov, 2001; Vaghasiya et al., 2007).

\section{CNS depressant activity Hole Cross Test}

The method used was done as described by Takagi et al. The animals were divided into control, standard and test groups ( $n=5$ per group). The control group received vehicle (water) whereas the test group received methanolic extract of Syzygium samarangens bark (at the doses of $100 \mathrm{mg} / \mathrm{kg}$ and $200 \mathrm{mg} / \mathrm{kg} \mathrm{p.o.)} \mathrm{and}$ standard group received diazepam at the dose of $1 \mathrm{mg} / \mathrm{kg}$ body weight orally. Each animal was then placed on one side of the chamber and the number of passages of each animal through the hole from one chamber to the other was recorded for 30 min on $0,30,60$ and 90 mins.during the study period.

\section{Open Field Test}

This experiment was carried out as described by Gupta et al., The animals were divided into control,standard and test groups ( $n=5$ per group). The control group received vehicle ( water), the test group received the crude extract (at the doses of $100 \mathrm{mg} / \mathrm{kg}$ and $200 \mathrm{mg} / \mathrm{kg}$ p.o.) and standard group received diazepam at the dose of $1 \mathrm{mg} / \mathrm{kg}$ body weight orally. The animals were placed on the floor of an open field $(100 \mathrm{~cm} \times 100$ $\mathrm{cm} \times 40 \mathrm{~cm} \mathrm{~h}$ ) divided into a series of squares. The number of squares visited by each animal was counted for 3 min on $0,30,60$ and 90 mins. during the study period.

\section{RESULT of CNS depressant activity \\ Open-field test}

In the open-field test the methanolic extract of Syzygium Samarangense bark extract exhibited a decrease in the movements of the test animals at all dose levels tested. The results were statistically significant for all doses and followed a dose-dependent response (Table 5).

\section{Hole-cross test}

Results of the hole-cross test followed a similar trend to the ones observed in the open-field test. They were statistically significant for all dose levels and followed a dose-dependent response. The depressing effect was most intense during the third (60 mins) observation periods (Table 4).

\section{CONCLUSION}

The results of the experiments suggest that the methanolic extract of Syzygium Samarangense bark may be used as an alternative or supplementary herbal remedy for the treatment of analgesic, inflammatory and in depressant disease. Because of its analgesic, anti-inflammatory and antidepressant effects, the methanolic extract of Syzygium Samarangense bark have beneficial effects together with drugs known for a strong analgesic, moderate anti-inflammatory as well as antidepressant effects. Thus the present study warrants further investigation involving components of the methanolic extract of Syzygium Samarangense bark for possible development of new class of analgesic and anti-inflammatory drugs.

\section{ACKNOWLEDGEMENTS}

It,s my pleasure to express my deep sense of gratitude and sincere thanks to my colleaguesLuthfunnesa, Mst. Shirajum Munira, Dr. Monirul Islam, Wahed Sayem and my students-Nasima Parvin, Md.Nasim for their kind co-operation in these research work.

\section{REFERENCES}

[1] Rakh, M.S. and S.R Chaudhary, 2010. Evaluation of CNS depressant activity of Momordica dioica roxbwild fruit pulp. International Journal of Pharmacy and Pharmaceutical Sciences,2(4):124-126

[2] Kumara, N.K.V.M,.R 2001. Identification of strategies to improve research on medicinal plants used in SriLanka. a WHO symposium; University of Ruhuna, Gally, Sri Lanka .

[3] Joshi, B., S. Lekhak and A. Sharma, 2009. Antibacterial property of different medicinal plants Ocimum sanctum, Cinnamomum zeylanicum, Xanthoxylum armatum and Origanum majorana. Kathmandu University Journal of Sciences Engineering and Technology, 5(1): 143-150.

[4] Sivarajan, V.V. and I. Balachandran, 2002.Ayurvedic drugs and their plant sources. Oxford and IBH publishing Co. Pvt. Ltd., New Delhi, pp: 271-272

[5] Clore;J.N;Stillman, j;Sugerman,H.Glucose-6-phosphate flux in vitro is increased in type 2 diabetes.Diabetes 2000,49,969-974.

[6] Resurreccion-Magno,M; Villasenor,I,Harada,N;Monde,K.Antihyperglycaemic flavonoids from Syzygium Samarangense (Blume) Merr. And perry. Phytother.Res 2005,19,246-251

[7] Wikipedea -"The Plant List: A Working List of All Plant Species". 
[8] Julia F. Morton (1987). Java apple-Fruits of Warm Climates. Miami, FL: Florida Flair Books. pp. 381-382

[9] Sanmugapriya, E. and S. Venkataraman, 2006. Toxicological investigations on Strychnos potatorum seeds in experimental models. Journal of Health Sciences, 52(4): 339- 343

[10] Ahmed, F., M.S.T. Selim, A.K. Das, and M.S.K. Choudhuri, 2004. Anti-inflammatory and antinociceptive activities of Lippia nodiflora Linn. Pharmazie, 59: 329-330.

[11] Dubuission, D., and S.G. Dennis, 1977. The formalin test: A quantitative study of the analgesia effects of morphine, meperidine and brain stem stimulation in rats and cats. Pian, 4: 167-174.

[12] Winter, C.A., E.A. Risley, and G.W. Nuss, 1962. Carrageenan induced oedema in hind paw of the rats as an assay of antiinflammatory drug. Proc. Soc. Exp. Bio. Med., 111:544-547.

[13] Ribeiro, R.A., M.L. Vale, S.M. Thomazzi, A.B. Paschoalato, S. Poole, S.H. Ferreira, and F.Q. Cunha, 2000. Involvement of resident macrophages and mast cells in the writhing nociceptive response induced by zymosan and acetic acid in mice. Eur. J. Pharmacol., 387:111-118.

[14] Voilley, N,. 2004. Acid-sensing ion channels (ASICs): New targets for the analgesic effects of Non-Steroid Anti-Inflammatory Drugs (NSAIDs). Curr. Drug Targets-Inflamm. Allergy, 3: 71-79.

[15] Hossain, M.M., M.S. Ali, A. Saha, and M. Alimuzzaman, 2006. Antinociceptive activity of whole plant extracts of Paederia foetida. Dhaka Uni. J. Pharm. Sci., 5: 67-69.

[16] Alam, B., S. Hossain, R. Habib, J. Ria, and A. Islam, 2012. Antioxidant and analgesic activities of Lannea coromandelica Linn. bark extract. Int. J. Pharmacol., 8: 224-233

[17] Kim, H.P., K.H. Son, H.W. Chang, and S.S. Kang, 2004. Anti-inflammatory plant flavonoids and cellular action mechanism. J. Pharm. Sci., 96: 229-245.

[18] Pritam, S.J., T. Amol, B.B. Sanjay, and J.S. Sanjay, 2011. Analgesic activity of Abelmoschus monihot Extracts. Int. J. Pharmacol., 7: 716-720.

[19] Hunskaar, S., and K. Hole, 1987. The formalin test in mice: Dissociation between inflammatory and non-inflammatory pain. Pain, 30:103-114.

[20] McNamara, C.R., J. Mandel-Brehm, D.M. Bautista, J. Siemens, K.L. Deranian, M. Zhao, M. Hayward, J.A. Chong, D. Julius, M.M. Moran, and C.M. Fanger, 2007. TRPA1 mediates formalin-induced pain. Proc. Nat. Aca. Sci.ence USA, 104: 1352513530.

[21] Kerstein, P.C., D.D. Camino, M.M. Morgan, and C.L. Stucky, 2009. Pharmacological blockade of TRPA1 inhibits mechanical firing in nociceptors. Mol. Pain, 5:19-25.

[22] Antonio, A.M., and A.R.M.S. Brito, 1998. Oral anti-inflammatory and anti-ulcerogenic activities of a hydroalcoholic extract and partitioned fractions of Turnera ulmifolia (Turneraceae). J. Ethnopharmacol., 61: 215-228.

[23] Gupta, M., U.K. Mazumder, P. Gomathi, and V.T. Selvan, 2006. Anti-inflammatory evaluation of leaves of Plumeria acuminate. BMC Com. Alt. Med., 6: 36-39.

[24] Sawadogo, W.R., R. Boly, M. Lompo, N, Some, C.E. Lamien, I.P. Guissou, and O.G. Nacoulma, 2006. Anti-inflammatory, analgesic and antipyretic activities of Dicliptera verticillata. Int. J. Pharmacol., 2: 435-438.

[25] Koblyakov, V.A., 2001. Free radicals and inflammation (progress in inflammation research series, 1999). Biochem., 66: 937-938.

[26] Vaghasiya, Y., R. Nair, and S. Chanda, 2007. Investigation of some piper species for anti-bacterial and anti-inflammatory property. Int. J. Pharmacol., 3: 400-405.

[27] Takagi K, Watanabe M, Saito H. 1971. Studies on the spontaneous movement of animals by the hole cross test: Effect of 2dimethylaminoethane. Its acylates on the central nervous system. Jpn. J. Pharmacol, 21: 797.

[28] Adzu, B., S. Amos, S.D. Kapu, and K.S. Gamaniel, 2003. Anti-inflammatory and anti-nociceptive effects of Sphaeranthus senegalensis. J. Ethnopharmacol., 84:169-174.

[29] Gupta BD, Dandiya PC, Gupta ML. 1971. A psychopharmacological analysis of behavior in rat. Jpn.J.Pharmacol, 21: 293.

Table 1: Effects of the methanolic extract of Syzygium samarangens bark on acetic acid-induced writhing in mice

\begin{tabular}{|c|c|c|c|}
\hline Groups & Dose $(\mathbf{m g} / \mathbf{k g})$ & No. of writhing & \% inhibition \\
\hline Group I & Vehicle & 35.60 & - \\
\hline Group II & 10 & 10.10 & $71.62^{*}$ \\
\hline Group III & 100 & 19.40 & $45.50^{*}$ \\
\hline Group IV & 200 & 12.14 & $65.89^{*}$ \\
\hline
\end{tabular}

Values are mean \pm SEM, $(n=5) ;{ }^{*} p<0.05$ as compared to vehicle control (One way ANOVA followed by Dunnet test). Group I animals received vehicle (water) Group II received Diclofenac Na (10 mg/kg body weight) Group III, IV were treated with $100 \mathrm{mg} / \mathrm{kg}$ and $200 \mathrm{mg} / \mathrm{kg}$ body weight (p.o.) of the methanolic extract of Syzygium samarangns bark.

Table 2: Effects of the methanolic extract of Syzygium samarangens bark hindpaw licking in the formalin test in mice

\begin{tabular}{|c|c|c|c|c|c|}
\hline Groups & $\begin{array}{c}\text { Dose } \\
(\mathrm{mg} / \mathrm{kg})\end{array}$ & Early phase $(\mathrm{Sec})$ & $\%$ protection & Late phase (Sec) & $\%$ protection \\
\hline Group-I & Vehicle & $36.66 \pm 1.38$ & - & $42.18 \pm 1.03$ & - \\
\hline Group-II & 10 & $16.03 \pm 0.90^{*}$ & 56.27 & $17.23 \pm 0.70^{*}$ & 59.15 \\
\hline Group-III & 100 & $19.0 \pm 2.2^{*}$ & 45.45 & $15.0 \pm 2.00^{*}$ & 57.39 \\
\hline Group-IV & 200 & $10.0 \pm 3.3^{*}$ & 70.45 & $9.00 \pm 2.7 *$ & 73.30 \\
\hline
\end{tabular}


Values are mean \pm SEM, $(n=5) ; * p<0.05$ as compared to vehicle control (One way ANOVA followed by Dunnet test). Group I animals received vehicle (water) Group II received Diclofenac Na $(10 \mathrm{mg} / \mathrm{kg}$ body weight) Group III, IV were treated with $100 \mathrm{mg} / \mathrm{kg}$ and $200 \mathrm{mg} / \mathrm{kg}$ body weight (p.o./per oral) of the methanolic extract of Syzygium samarangens bark.

Table 3: Effect of methanolic extract of Syzygium samarengense in carageenan induced inflammation.

\begin{tabular}{|c||c||c|c|c|c|c|c|c|c|}
\hline & \multicolumn{4}{|c|}{} & \multicolumn{4}{|c|}{ Oedema diameter (mm) } & \multicolumn{4}{c|}{ Inhibition (\%) } \\
\hline Group & $\begin{array}{c}\text { Dose } \\
(\mathbf{m g} / \mathbf{k g})\end{array}$ & $\mathbf{1 h}$ & $\mathbf{2 h}$ & $\mathbf{3 h}$ & $\mathbf{4 h}$ & $\mathbf{1 h}$ & $\mathbf{2 h}$ & $\mathbf{3 h}$ & $\mathbf{4 h}$ \\
\hline Group I & Vehicle & $5.4 \pm 0.20$ & $6.35 \pm 0.49$ & $6.06 \pm 0.58$ & $6.3 \pm 0.84$ & & & & \\
\hline Group II & 10 & $2.4 \pm 0.47^{*}$ & $1.86 \pm 0.46^{*}$ & $1.44 \pm 0.3^{*}$ & $1.0 \pm 0.32^{*}$ & 55.33 & 70.72 & 76.25 & 84.18 \\
\hline Group III & 100 & $4.5 \pm 0.68^{*}$ & $4.2 \pm 0.61^{*}$ & $3.7 \pm 0.51^{*}$ & $3.2 \pm 0.49^{*}$ & 17.68 & 34.38 & 38.96 & 50.02 \\
\hline Group IV & 200 & $3.8 \pm 0.50^{*}$ & $3.62 \pm 0.56^{*}$ & $3.4 \pm 0.46^{*}$ & $2.54 \pm 0.57^{*}$ & 29.86 & 43.01 & 46.55 & 59.82 \\
\hline
\end{tabular}

Values are mean \pm SEM, $(\mathrm{n}=5) ; * \mathrm{p}<0.05$, Dunnet test as compared to vehicle control. Group I animals received vehicle ( water), Group II received Ibuprofen $10 \mathrm{mg} / \mathrm{kg}$ body weight, Group III and Group IV were treated with $100 \mathrm{mg} / \mathrm{kg}$ and $200 \mathrm{mg} / \mathrm{kg}$ body weight (p.o.) of the methanolic extract of Syzygium samarangens bark.

Table 4. Effect of methanolic extract of Syzygium samarangens bark on hole cross test in mice

\begin{tabular}{|l|l|l|l|l|l|l|}
\hline & & \multicolumn{5}{|c|}{ Number of Movements } \\
\cline { 3 - 7 } Group & Dose & $0 \mathrm{~min}$ & $30 \mathrm{~min}$ & $60 \mathrm{~min}$ & $90 \mathrm{~min}$ & $120 \mathrm{~min}$ \\
\hline Group-I & $10 \mathrm{ml} / \mathrm{kg}$, & $118.4 \pm 1.20$ & $118 \pm 1.30$ & $115.4 \pm 0.50$ & $117.4 \pm 1.16$ & - \\
\hline Group-II & $1 \mathrm{mg} / \mathrm{kg}$, & $117.2 \pm 1.15^{*}$ & $64.6 \pm 0.43^{*}$ & $38.8 \pm 0.58^{*}$ & $15.8 \pm .86^{*}$ & - \\
\hline Group-III & $100 \mathrm{mg} / \mathrm{kg}$ & $3 \pm 1.00^{*}$ & $3 \pm 1.61^{*}$ & $1.8 \pm 0.91^{*}$ & $2 \pm 1.11^{*}$ & - \\
\hline Group-IV & $200 \mathrm{mg} / \mathrm{kg}$ & $3 \pm 1.3^{*}$ & $4 \pm 1.7^{*}$ & $2.0 \pm 1.2^{*}$ & $3 \pm 1.2^{*}$ & - \\
\hline
\end{tabular}

Values are mean \pm SEM, $(\mathrm{n}=6) ; * \mathrm{p}<0.05$, Dunnet test as compared to vehicle control. Group I animals received vehicle (water), Group II received diazepam $1 \mathrm{mg} / \mathrm{kg}$ body weight, Group III and Group IV were treated with $100 \mathrm{mg} / \mathrm{kg}$ and $200 \mathrm{mg} / \mathrm{kg}$ body weight (p.o.) of the methanolic extract of Syzygium samarangens bark.

Table 5. Effect of methanolic extract of Syzygium samarangens bark on Open Field test in mice

\begin{tabular}{|l|l|l|l|l|l|l|}
\hline \multirow{2}{*}{ Group } & \multirow{5}{*}{ Dose } & \multicolumn{5}{|c|}{ Number of Movements } \\
\cline { 3 - 7 } & $0 \mathrm{~min}$ & $30 \mathrm{~min}$ & $60 \mathrm{~min}$ & $90 \mathrm{~min}$ & $120 \mathrm{~min}$ \\
\hline Group-I & $10 \mathrm{ml} / \mathrm{kg}$ & $12.8 \pm 1.15$ & $13 \pm 1.41$ & $13.6 \pm 0.92$ & $14.2 \pm 0.86$ & - \\
\hline Group-II & $1 \mathrm{mg} / \mathrm{kg}$ & $11.2 \pm 0.58$ & $6 \pm 0.70^{*}$ & $4.0 \pm 0.83^{*}$ & $2.4 \pm 0.81^{*}$ & - \\
\hline Group-III & $100 \mathrm{mg} / \mathrm{kg}$, & $194 \pm 7.00$ & $56 \pm 4.49^{*}$ & $49 \pm 2.15^{*}$ & $38 \pm 4.05^{*}$ & - \\
\hline Group-IV & $200 \mathrm{mg} / \mathrm{kg}$, & $146.2 \pm 7.4$ & $85 \pm 2.7^{*}$ & $48 \pm 3.4^{*}$ & $29 \pm 3.5^{*}$ & - \\
\hline
\end{tabular}

Values are mean \pm SEM, $(\mathrm{n}=5) ; * \mathrm{p}<0.05$, Dunnet test as compared to vehicle control. Group I animals received vehicle (water), Group II received diazepam $1 \mathrm{mg} / \mathrm{kg}$ body weight, Group III and Group IV were treated with $100 \mathrm{mg} / \mathrm{kg}$ and $200 \mathrm{mg} / \mathrm{kg}$ body weight (p.o./per oral) of the methanolic extract of Syzygium samarangens bark. 